ISSN 0067-1975 (print), ISSN 2201-4349 (online)

https://doi.org/10.3853/j.2201-4349.70.2018.1712

urn:lsid:zoobank.org:pub:AD2C3EEC-B184-43EA-8B98-52CD77D39B5A

Peter K. L. Ng orcid.org/0000-0001-5946-0608

Shane T. Ahyong orcid.org/0000-0002-2820-4158

\title{
New Species of Reef Spider Crabs of the Genus Schizophroida Sakai, 1933 (Crustacea: Brachyura: Majidae) from the Western Pacific
}

\author{
Peter K. L. NG ${ }^{1}$ and Shane T. Ahyong ${ }^{2 *}$ \\ ${ }^{1}$ Lee Kong Chian Natural History Museum, Faculty of Science, National University of Singapore, \\ 2 Conservatory Drive, Singapore 117377, Republic of Singapore \\ 2 Australian Museum Research Institute, Australian Museum, \\ 1 William Street, Sydney NSW 2010, Australia, and \\ School of Biological, Earth \& Environmental Sciences, University of New South Wales \\ NSW 2052, Australia \\ peterng@nus.edu.sg·shane.ahyong@austmus.gov.au
}

\begin{abstract}
Prior to the present study, the spider crab genus Schizophroida Sakai, 1933, included only the type species, S. hilensis Rathbun, 1906 (described from Hawaii but apparently wide-ranging in the western Pacific), and two other Pacific species, S. simodaensis Sakai, 1933 (Japan) and S. moai Ng \& Boyko, 2017 (Easter Island). Outside of Hawaii, S. hilensis has been reported from the southwestern Pacific: Australia, New Zealand and New Caledonia. Review of the southwestern Pacific material showed that Schizophroida from Australia and New Zealand belongs to a separate species, and is described as new to science. The New Caledonian record is based on an incomplete juvenile female, which also appears to be new to science, but is not formally named pending collection of more complete specimens. A second new species of Schizophroida is also described from specimens collected from Taiwan and Guam. A key to the species of Schizophroida is provided.
\end{abstract}

KeYwords. Decapoda; spider crab; Australia; Lord Howe Island; Taiwan; Guam; western Pacific

NG, Peter K. L., AND Shane T. Ahyong. 2018. New species of reef spider crabs of the genus Schizophroida Sakai, 1933 (Crustacea: Brachyura: Majidae) from the Western Pacific. Records of the Australian Museum 70(4): 377-390. https://doi.org/10.3853/j.2201-4349.70.2018.1712

The spider crab genus Schizophroida Sakai, 1933, was established for three Indo-West Pacific species: Schizophrys hilensis Rathbun, 1906 (Hawaii), Schizophroida simodaensis Sakai, 1933 (Japan), and Schizophroida manazuruana Sakai, 1933 (Japan). Sakai (1933) distinguished Schizophroida from Schizophrys White, 1848, by its members lacking an accessory spine on the rostral spines and the absence of an anterior accessory spine on the postorbital lobe. No type species of the genus was selected by Sakai (1933), with Griffin \& Tranter (1986) subsequently selecting S. hilensis as the type species.
Ng \& Boyko (2017) reviewed the taxonomy of Schizophroida and showed that some of the taxonomic characters used by previous workers (e.g., Rathbun, 1906; Sakai, 1933, 1938, 1976; Buitendijk, 1939; Takeda, 1977; Griffin \& Tranter, 1986) are not reliable. Ng \& Boyko (2017) observed that the relative length of the rostral spines varies to some degree, the smoothness of the carpus of the cheliped was associated with sex (fully grown males have a granulose carpus), and the proportions of the ambulatory legs were sexually dimorphic, being proportionally longer and more slender in males. Several new species-specific

* author for correspondence 
characters were also identified, e.g., the proportional width of the supraorbital eave, carapace armature along the lateral margin, shape of the carapace spines, shape of the male pleon and structure of the male first gonopod. As a result, they synonymised S. manazuruana Sakai, 1933, under $S$. simodaensis Sakai, 1933, confirming what Griffin \& Tranter (1986) had surmised from published accounts. Ng \& Boyko (2017) described a new species from Easter Island, S. moai, but also indicated the presence of probable undescribed species from the northwestern (Guam and Taiwan) and southwestern Pacific (Australia, New Zealand and New Caledonia; Griffin \& Tranter, 1986). The present paper addresses these remaining species of Schizophroida.

\section{Material and methods}

Material examined is deposited in the Australian Museum, Sydney (AM), Kanagawa Prefectural Museum, Odawara, Japan (KPM); Los Angeles County Museum, U.S.A. (LACM); Marine Invasives Taxonomic Service, National Institute of Water and Atmospheric Research, Wellington, New Zealand (NIWA(MITS)); National Museum of Natural History, Smithsonian Institution, Washington, D.C., U.S.A. (USNM); National Taiwan Ocean University, Keelung, Taiwan (NTOU); and Zoological Reference Collection (ZRC) of the Lee Kong Chian Natural History Museum, National University of Singapore. Carapace length (cl) is the total length and includes the rostral spines; postrostral carapace length $(\mathrm{pcl})$ is measured along the midline from the base of the rostral sinus to posterior margin of the carapace; carapace width (cw) is the greatest width excluding spines. Measurements are in millimetres ( $\mathrm{mm}$ ). The abbreviations G1 and G2 are for the male first and second gonopods, respectively. Following Griffin \& Tranter (1986), we use the term rostral spines for the two slender processes projecting forwards from the carapace front, and interantennular spine for the short ventromedial projection arising from the interantennular septum. These three processes have also been termed pseudorostral and rostral spines (for the lateral and median spines respectively) (e.g., Ng \& Richer de Forges, 2012). The homology of these three processes with respect to the rostrum of other decapods is presently uncertain. Whether only the median process or all three processes represent the "true" rostrum (i.e., the rostrum is trifid) requires further study.

\section{Comparative material. Schizophroida hilensis (Rathbun,} 1906) (all Hawaii): USNM 29794, lectotype male (cl 16.1 $\mathrm{mm}, \mathrm{pcl} 13.0 \mathrm{~mm}$, cw $9.1 \mathrm{~mm}$ ), 2 paralectotype females (cl $19.4 \mathrm{~mm}$, pcl $16.5 \mathrm{~mm}$, cw $11.9 \mathrm{~mm}$; cl $16.2 \mathrm{~mm}$, cw 10.6 mm), Hilo, coll. H. Henslow; ZRC 2000.0417, 1 male (cl 18.5 mm, pcl 14.9 mm, cw 11.0 mm), Magic Island, Ala Moana, Waikiki, Honolulu, coll. P. K. L. Ng \& S. H. Tan, 22 January 2000; ZRC 2000.0459, 1 male (cl $12.4 \mathrm{~mm}$, pcl $10.1 \mathrm{~mm}$, cw $7.3 \mathrm{~mm}$ ), $1.2 \mathrm{~m}$, on seaweed wall, Fort DeRussy, O'ahu, coll. D. Takaoka, 14 September 1998; ZRC 2000.0502, 1 male (cl $12.5 \mathrm{~mm}$, pcl $9.6 \mathrm{~mm}$, cw $6.8 \mathrm{~mm}$ ), north of Mökapu Peninsula, Moku Manu Island, O'ahu, coll. R. De Felice \& S. Coles, 26 January 2000; AM P29816, 4 males (cl 9.3 mm, pcl $7.4 \mathrm{~mm}$, cw $5.2 \mathrm{~mm}$ to cl $14.0 \mathrm{~mm}$, pcl $11.4 \mathrm{~mm}$, cw 8.3 $\mathrm{mm}$ ), 1 ovigerous female (cl $19.1 \mathrm{~mm}, \mathrm{pcl} 16.3 \mathrm{~mm}, \mathrm{cw} 12.0$ $\mathrm{mm}$ ), 2 juvenile females (cl $10.6 \mathrm{~mm}$, pcl $8.4 \mathrm{~mm}$, cw 6.1 $\mathrm{mm}$; cl $13.5 \mathrm{~mm}$, pcl $11.1 \mathrm{~mm}$, cw $8.0 \mathrm{~mm}$ ), Waikiki, reef, under stones near shore, coll. M. Ward, 24-30 August 1927; AM P29822, 1 male (cl $17.0 \mathrm{~mm}$, pcl $13.6 \mathrm{~mm}$, cw $9.7 \mathrm{~mm}$ ), 1 pre-spawning female (cl $19.3 \mathrm{~mm}$, pcl $16.2 \mathrm{~mm}, \mathrm{cw} 12.0$ mm), Hawaii; AM P29823, 1 male (cl $15.8 \mathrm{~mm}$, pcl 12.7 $\mathrm{mm}$, cw $8.9 \mathrm{~mm}$ ), 1 ovigerous female (cl $14.4 \mathrm{~mm}$, pcl 12.2 mm, cw $9.3 \mathrm{~mm}$ ), Hawaii; AM P80450, 1 juvenile female (cl 12.8, pcl $10.5 \mathrm{~mm}$, cw $7.5 \mathrm{~mm}$ ), Hilo, Big Island, $19.7^{\circ} \mathrm{N}$ 155.1 ${ }^{\circ} \mathrm{W}$, coll. Mortensen, 7 April 1914.

Schizophroida simodaensis Sakai, 1933 (all Japan): ZRC 2016.0154, 1 male (cl $28.6 \mathrm{~mm}$, pcl $23.0 \mathrm{~mm}$, cw $16.6 \mathrm{~mm})$, Kii-Nagashima, Mie Prefecture, coll. M. Saba, 14 April 1977; ZRC 2008.0695, 1 female (damaged, pcl $36.3 \mathrm{~mm}$, cw 24.6 $\mathrm{mm}$ ), no precise locality; KPM-NH0124024, 1 male (cl 31.9 $\mathrm{mm}$, cw $28.7 \mathrm{~mm}$ ), Minabe, Wakayama Prefecture, Kishunada Sea, coll. 1972; KPM-NH0124036, 3 males (cl 34.5 mm, cw $19.6 \mathrm{~mm}$; cl $34.5 \mathrm{~mm}$, cw $20.7 \mathrm{~mm}$; cl 36.6 mm, cw 22.2 $\mathrm{mm})$, Minabe, Wakayama Prefecture, Kishu-nada Sea; KPMNH0104058, 1 male (cl $36.3 \mathrm{~mm}$, cw $21.5 \mathrm{~mm}$ ), Minabe, Wakayama Prefecture, Kishu-nada Sea; KPM-NH0104064, 1 female (cl $30.9 \mathrm{~mm}$, cw $20.3 \mathrm{~mm}$ ), Minabe, Wakayama Prefecture, Kishu-nada Sea; KPM-NH0104086, 1 male (cl $34.5 \mathrm{~mm}$, cw $20.5 \mathrm{~mm}$ ), no precise locality, 7 May 1934; KPM-NH0104136, 1 male (cl $26.8 \mathrm{~mm}$, cw $14.7 \mathrm{~mm}$ ), Tosa Bay, 1967; KPM-NH0104141, 2 males (cl 30.0 mm, cw 17.0 $\mathrm{mm}$; cl 32.7 mm, cw $29.0 \mathrm{~mm}$ ), Tosa Bay; KPM-NH0104355, $1 \mathrm{male}$ (cl $35.9 \mathrm{~mm}$, cw $21.1 \mathrm{~mm}$ ), 1 female (cl $30.2 \mathrm{~mm}$, cw $19.5 \mathrm{~mm}$ ), Minabe, Wakayama Prefecture, Kishu-nada Sea; KPM-NH0104367, 1 female (cl $26.8 \mathrm{~mm}$, cw $17.7 \mathrm{~mm}$ ), Minabe, Wakayama Prefecture, Kishu-nada Sea; KPMNH0104447, 1 male (cl 27.9 mm, cw $16.0 \mathrm{~mm}$ ), Minabe, Wakayama Prefecture, Kishu-nada Sea; KPM-NH0104472, 3 females (cl $23.9 \mathrm{~mm}$, cw $15.4 \mathrm{~mm}$; cl $25.7 \mathrm{~mm}$, cw $16.7 \mathrm{~mm}$; cl $25.0 \mathrm{~mm}$, cw $17.5 \mathrm{~mm}$ ), Minabe, Wakayama Prefecture, Kishu-nada Sea; KPM-NH0104486, 1 male (cl 27.6 mm, cw $16.1 \mathrm{~mm}$ ), Kushimoto, Wakayama Prefecture; KPMNH0104517, 1 female (cl 28.8 mm, cw17.5 mm), Shirahama, Wakayama Prefecture, Kishu-nada Sea; KPM-NH0104527, 1 female (cl $29.9 \mathrm{~mm}$, cw $18.5 \mathrm{~mm}$ ), Nada-cho, Gobo, Wakayama Prefecture, Kishu-nada Sea; KPM-NH0104562, 1 male (cl 36.5 mm, 21.8 mm), Hatsushima Islet, Sagami Bay, Atami, Shizuoka Prefecture; KPM-NH0104631, 1 male (cl $33.8 \mathrm{~mm}$, cw $28.8 \mathrm{~mm}$ ), Shirahama, Wakayama Prefecture, Kishu-nada Sea, April 1964; KPM-NH0104643, 1 male (cl $29.2 \mathrm{~mm}$, cw $17.5 \mathrm{~mm}$ ), Kushimoto, Wakayama Prefecture; KPM-NH0104684, 1 female (cl $26.5 \mathrm{~mm}$, cw $16.4 \mathrm{~mm}$ ), Nada-cho, Gobo, Wakayama Prefecture, Kishu-nada Sea; KPM-NH0104924, 1 male (cl 30.3 mm, cw 17.8 mm), KiiNagashima, Kihoku (= Kii-Nagashima), Mie Prefecture, Kumano-nada Sea.

Schizophroida moai Ng \& Boyko, 2017 (all Easter Island): USNM 1253232, holotype male (cl $32.2 \mathrm{~mm}$, cw $21.2 \mathrm{~mm}$ ), Anakena, coll. C. B. Boyko \& S. Reanier, 30 August 1999. Paratypes: ZRC 2016.0155, 1 ovigerous female (cl $29.8 \mathrm{~mm}$, pcl $24.5 \mathrm{~mm}$, c $18.5 \mathrm{~mm}$ ), Anakena, coll. C. B. Boyko \& S. Reanier, 30 August 1999; ZRC 2016.0156, 1 male (pcl 16.7 $\mathrm{mm}$, c $12.6 \mathrm{~mm}$ ), no precise locality, coll. L. H. DiSalvo, 1985; ZRC 2016.0157, 1 juvenile female (cl $13.1 \mathrm{~mm}$, pcl $9.5 \mathrm{~mm}$, cw $6.8 \mathrm{~mm}$ ), no precise locality, coll. L. H. DiSalvo, 1985; LACM CR1999-1, 1 juvenile (cl 2.5 mm, cw 4.5 mm), no precise locality, coll. C. B. Boyko, August 1999; LACM CR1999-2, 1 juvenile (cl 1.9 mm, cw $2.8 \mathrm{~mm}$ ), Ahu Tepeu, 15.2 m, coll. H. Tonnemacher, 29 August 1999. 
Schizophroida sp.: AM P29817, 1 juvenile female (cl $19.0 \mathrm{~mm}$, pcl $15.2 \mathrm{~mm}, \mathrm{cw} 10.4 \mathrm{~mm}$ ), off New Caledonia, $22^{\circ} 48.5^{\prime} \mathrm{S} 167^{\circ} 36.5^{\prime} \mathrm{E}, 85-100 \mathrm{~m}$, large bottom dredge, RV Kimbla K4/71/4, coll. J. Paxton \& P. Colman, 8 May 1971.

\section{Taxonomy}

\section{Superfamily Majoidea Samouelle, 1819 \\ Family Majidae Samouelle, 1819 \\ Genus Schizophroida Sakai, 1933}

\section{Schizophroida colemani sp. nov.}

\author{
Figs $1 \mathrm{~A}-\mathrm{C}, 2 \mathrm{~A}, \mathrm{~B}, 3,5 \mathrm{~A}, 10 \mathrm{~A}-\mathrm{C}$ \\ Schizophrys hilensis.-Chilton, 1911: 546, 562-563.-Duffy \\ \& Ahyong, 2015: 83. [Not Schizophrys hilensis Rathbun, \\ 1906]. \\ Schizophroida hilensis. - Griffin \& Tranter, 1986: 238-243, \\ fig. $68 \mathrm{c}, \mathrm{c}$, pl. 19 [part, Australian and New Zealand \\ specimens only].-Coleman, 2002: 56.-Poore, 2004: \\ 380, fig. 114c.- -Takeda \& Webber, 2006: 196, 232, fig. \\ 3A.-Williams et al., 2008: 5.-Webber et al., 2010: \\ 227.-Ahyong \& Wilkens, 2011: tab. 1.-Yaldwyn \\ \& Webber, 2011: 239.-Ahyong, 2015: 429. [Not \\ Schizophroida hilensis (Rathbun, 1906)].
}

Holotype: AM P19606, male (cl $33.5 \mathrm{~mm}$, pcl $27.9 \mathrm{~mm}$, cw 20.2 mm), Ned's Beach, coll. I. Bennett, May 1964. Paratypes: AM P30966, 1 male (cl $18.4 \mathrm{~mm}$, pcl $15.6 \mathrm{~mm}$, cw $10.9 \mathrm{~mm}$ ), 1 ovigerous female (cl $15.2 \mathrm{~mm}$, pcl 13.5 $\mathrm{mm}$, cw $9.2 \mathrm{~mm}$ ), Deakon's Reef, $22 \mathrm{~m}$, coll. N. Coleman, 30 November 1979; ZRC 2017.1280, 1 male (cl $18.0 \mathrm{~mm}$, pcl $14.9 \mathrm{~mm}$, cw $10.3 \mathrm{~mm}$ ), Flat Rock, $25 \mathrm{~m}$, AMPI Crust 866, coll. N. Coleman, 22 Feb 1979; AM P29818, 1 juvenile female (cl $9.9 \mathrm{~mm}$, pcl $8.7 \mathrm{~mm}$, cw $5.7 \mathrm{~mm}$ ), Flat Rock, 25 m, coll. N. Coleman, 22 Feb 1979; AM P29819, 1 male (cl $19.4 \mathrm{~mm}$, pcl $16.2 \mathrm{~mm}$, cw $11.4 \mathrm{~mm}$ ), Erscott's Hole, $3 \mathrm{~m}$, AMPI Crust No. 860, coll. N. Coleman, 15 February 1979; AM P80451, 1 male (cl $18.5 \mathrm{~mm}$, pcl $15.4 \mathrm{~mm}$, cw $10.3 \mathrm{~mm}$ ), Erscott's Hole, 4 m, AMPI Crust 954, coll. N. Coleman, 13 December 1979. All Lord Howe Island.

Other material examined. Australia.-New South Wales: AM P53496 1 ovigerous female (cl $26.8 \mathrm{~mm}$, pcl $22.9 \mathrm{~mm}$, cw $16.0 \mathrm{~mm}$ ), between Jervis Bay and Gabo Island, NSW, $35^{\circ} 03^{\prime} \mathrm{S} 150^{\circ} 44^{\prime} \mathrm{E}, 30 \mathrm{~m}$, coll. L. Vail \& V. Harriott, March 1981.--LoRD Howe IsLAND, Tasman Sea: AM P29820, 1 juvenile female (cl $11.6 \mathrm{~mm}$, pcl $9.8 \mathrm{~mm}$, cw $6.8 \mathrm{~mm}$ ), Ball's Pyramid, 10 m, AMPI Crust No. 875, coll. N. Coleman, 24 February 1979; AM P10301, 2 juvenile females (cl $16.1 \mathrm{~mm}$, pcl $14.0 \mathrm{~mm}$, cw $10.0 \mathrm{~mm}$; cl $20.3 \mathrm{~mm}$, pcl $17.2 \mathrm{~mm}$, cw $12.0 \mathrm{~mm}$ ), no specific locality; AM P46665, 1 juvenile female (cl $13.3 \mathrm{~mm}$, pcl $11.2 \mathrm{~mm}$, cw $7.5 \mathrm{~mm}$ ), Malabar, $15 \mathrm{~m}$, AMPI Crust No. 1007, coll. N. Coleman, 23 February 1980; AM P5288, 2 males (cl $9.0 \mathrm{~mm}$, pcl $7.6 \mathrm{~mm}$, cw $5.4 \mathrm{~mm}$; cl $10.4 \mathrm{~mm}$, pcl $8.8 \mathrm{~mm}$, cw $6.3 \mathrm{~mm}$ ), no specific locality; AM P29821, 1 male (cl 9.0, pcl $7.5 \mathrm{~mm}$, cw $5.3 \mathrm{~mm}$ ), 1 juvenile female (cl $24.7 \mathrm{~mm}$, pcl $21.2 \mathrm{~mm}$, cw $14.9 \mathrm{~mm}$ ), no specific locality, coll. L. Clark, April 1932.-TASMAn Sea: AM P39993, 1 male (cl $8.8 \mathrm{~mm}$, pcl $6.9 \mathrm{~mm}$, cw $4.7 \mathrm{~mm}$ ), Elizabeth Reef, 29 $57.8^{\prime} \mathrm{S}$ $159^{\circ} 04.7^{\prime} \mathrm{E}$, outer slope, southern face, St. 36, coll. Australian Museum party, 11 December 1987; AM P40007, 1 juvenile female (cl $8.8 \mathrm{~mm}$, pcl $7.3 \mathrm{~mm}$, cw $5.1 \mathrm{~mm}$ ), Elizabeth Reef, 29 $57.7^{\prime} \mathrm{S} 159^{\circ} 02.8^{\prime} \mathrm{E}$, SW outer slope, St. 34, coll. Australian Museum party, 11 December 1987.

New Zealand. Kermadec Islands: AM P88937, 1 male (cl 3.7 mm, pcl $3.1 \mathrm{~mm}$, cw $2.1 \mathrm{~mm}$ ), Stawell Shoal, N of Stella Passage, $30^{\circ} 31.778^{\prime} \mathrm{S}$ $178^{\circ} 33.570^{\prime} \mathrm{W}, 21-24 \mathrm{~m}$, under encrusting coral on rock, K2011-92-8, coll. S. Keable \& A. Reid, 25 May 2011; AM P88909, 3 males (cl 4.3, pcl 3.7 mm, cw $2.7 \mathrm{~mm}$ to cl $11.1 \mathrm{~mm}$, pcl $8.9 \mathrm{~mm}$, cw $6.4 \mathrm{~mm}$ ), 4 females (cl 7.6 $\mathrm{mm}$, pcl $6.0 \mathrm{~mm}$, cw $4.6 \mathrm{~mm}$ to cl $14.2 \mathrm{~mm}$, pcl $11.6 \mathrm{~mm}$, cw $8.3 \mathrm{~mm}$ ), W side $1^{\prime}$ Esperance Rock, $31^{\circ} 21.252^{\prime} \mathrm{S} 178^{\circ} 49.593^{\prime} \mathrm{W}, 12-20 \mathrm{~m}$, rock walls, shelly sediment, sponges \& coral scrapings, K2011-99-13, coll. S. Keable \& A. Reid, 26 May 2011; AM P89040, 1 male (cl $6.0 \mathrm{~mm}$, pcl $4.9 \mathrm{~mm}$, cw $3.6 \mathrm{~mm}$ ), Fishing Rock landing, Raoul Island, $29^{\circ} 14.552^{\prime} \mathrm{S} 177^{\circ} 54.215^{\prime} \mathrm{W}$, 5 m, K2011-49-1, scrapings from rock wall, 17 May 2011; AM P89041, 1 juvenile male (cl $5.3 \mathrm{~mm}$, pcl $4.3 \mathrm{~mm}$, cw $3.1 \mathrm{~mm}$ ), Dept of Conservation landing site, W side North Meyer Island, $29^{\circ} 14.674^{\prime} \mathrm{S} 177^{\circ} 52.688^{\prime} \mathrm{W}, 1 \mathrm{~m}$, intertidal pools, K2011-5-6, coll. T. Trnski, 12 May 2011; AM P89274, 4 males (cl $4.6 \mathrm{~mm}$, pcl $4.1 \mathrm{~mm}$, cw $2.9 \mathrm{~mm}$ to $\mathrm{cl} 13.0 \mathrm{~mm}$, pcl $10.7 \mathrm{~mm}$, cw $7.8 \mathrm{~mm}$ ), 4 females (cl $7.1 \mathrm{~mm}$, pcl $5.9 \mathrm{~mm}$, cw $4.3 \mathrm{~mm}$ to $\mathrm{cl} 9.4 \mathrm{~mm}$, pcl $8.1 \mathrm{~mm}$, cw $6.0 \mathrm{~mm}$ ), Fishing Rock landing, Raoul Island, $29^{\circ} 14.552^{\prime} \mathrm{S}$ $177^{\circ} 54.215^{\prime} \mathrm{W}, 5 \mathrm{~m}, \mathrm{~K} 2011-49-4$, scrapings from rock wall, 17 May 2011. BAY OF ISLANDS, NORTH ISLAND: NIWA(MITS) 21755, 1 ovigerous female (cl $27.1 \mathrm{~mm}$, pcl $23.2 \mathrm{~mm}$, cw $16.7 \mathrm{~mm}$ ), from biofouling on floating wreck, BNZ1761CB2-CB, 10 March 2007.

Diagnosis. Rostral spines subparallel, margins straight, shorter than $0.25 \mathrm{pcl}$. Carapace protogastric region with transverse row of 4 distinct tubercles in adults; posterolateral margin with subdorsal tubercle between posteromedian spines and posterior branchial marginal spine; marginal branchial spines and posteromedian spines straight. Supraorbital eave moderately broad transversely, anterior width narrower than half basal width of rostral spine; intercalated spine prominent, separated from posterior spine of supraorbital eve by narrow U-shaped sinus. Basal antennal article with inner distal spine longer than outer. G1 with distal one-third distinctly curving laterally to about $50^{\circ}$ to longitudinal axis.

Description. Carapace (Figs 1A-C, 2A, B) distinctly pyriform, longer than wide, regions weakly defined, surface densely covered with coarse straight and hooked setae. Rostral spines $0.13-0.22 \mathrm{pcl}$, margins straight, subparallel, occasionally slightly divergent in small juveniles. Supraorbital eave moderately broad transversely, anterior width narrower than half basal width of rostral spine; intercalated spine prominent, triangular, directed anterolaterally, separated from posterior spine of supraorbital eave by narrow U-shaped sinus. Carapace postfrontal region with longitudinal row of 2 tubercles behind each rostral spine; gastric region with 5 distinct tubercles: protogastric region with transverse row of 4 tubercles; mesogastric region with 1 tubercle; cardiac region with 2 low prominences; intestinal region with distinct median tubercle. Hepatic region inflated; prominent, conical, anterolaterally directed spine, larger than branchial spines; small subhepatic granules. Lateral branchial margin with 4 spines; posterior branchial margin with blunt subdorsal tubercle positioned midway between last branchial spine and paired posterior carapace spines. Posterior carapace spines straight, directed posteriorly, inclined slightly dorsad.

Epistome (Fig. 3A, B) with stout anteroventrally directed spine at base of each antennular sinus. Interantennular septum cristate; interantennular spine directed ventrally, not visible in dorsal view (Figs 2A, B). Basal antennal article distally bispinous, inner spine longer than outer spine.

Maxilliped 3 merus with rounded proximomesial lobe, margins usually with small denticles, distomesial margin with small spine; ischium distomesially auriculiform (Fig. 3C).

Cheliped 1.29-1.90 pcl (adult males), 1.02-1.21 pcl (adult females); articles subcylindrical to subovate in cross-section. Propodal palm smooth, fingers with gape in adult males, pollex occlusal margin with blunt tooth near midlength. 


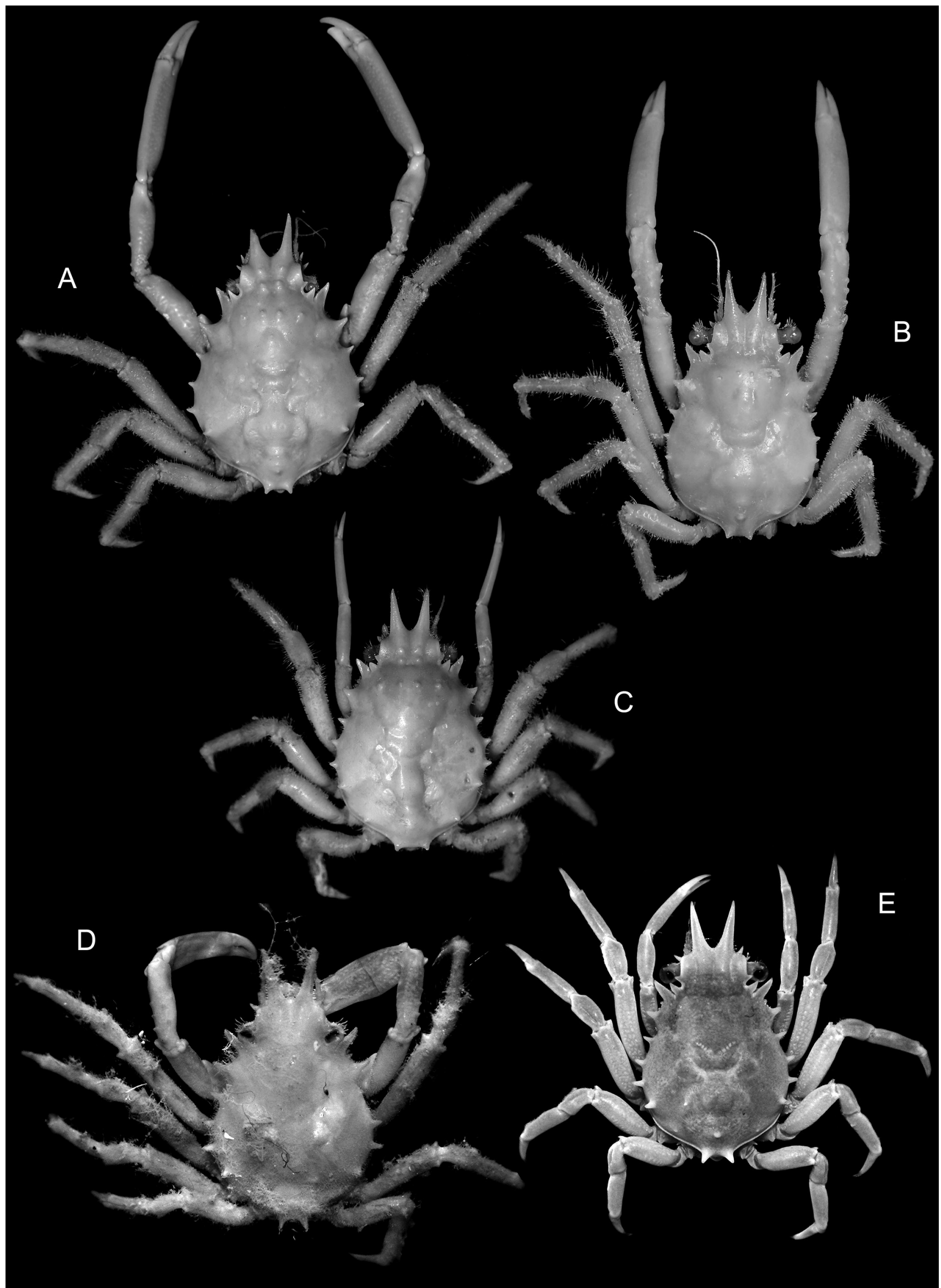

Figure 1. Schizophroida spp., dorsal habitus. (A) S. colemani sp. nov., male holotype, cl 33.5 mm, Lord Howe Island, AM P19606; (B) S. colemani sp. nov., male paratype, cl $18.0 \mathrm{~mm}$, Lord Howe Island, ZRC 2017.1280; (C) S. colemani sp. nov., ovigerous female, cl 26.8 mm, between Jervis Bay and Gabo Island, NSW, AM P53496; (D) S. hilensis (Rathbun, 1906), male, cl 18.5 mm, Hawaii, ZRC 2000.417; (E) S. hilensis (Rathbun, 1906), male, cl 12.4 mm, Hawaii, ZRC 2000.459. 


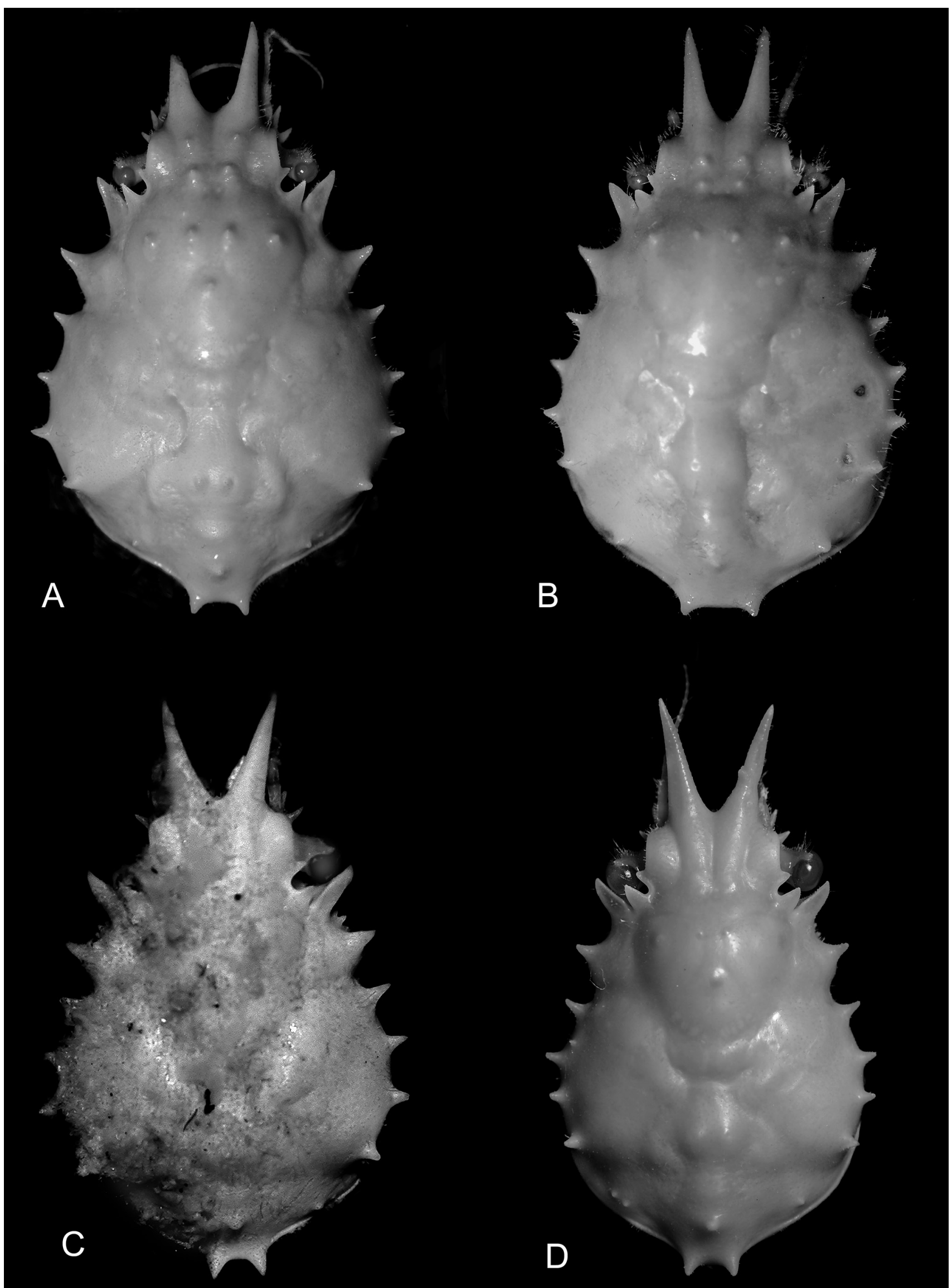

Figure 2. Schizophroida spp., carapace (all or most setae removed). (A) S. colemani sp. nov., male holotype, cl 33.5 mm, Lord Howe Island, AM P19606; (B) S. colemani sp. nov., ovigerous female, cl $26.8 \mathrm{~mm}$, between Jervis Bay and Gabo Island, NSW, AM P53496; (C) S. hilensis (Rathbun, 1906), male lectotype, cl $16.1 \mathrm{~mm}$, Hawaii, USNM 29794; (D) Schizophroida sp., juvenile female, cl 19.0 mm, New Caledonia, AM P29817. 


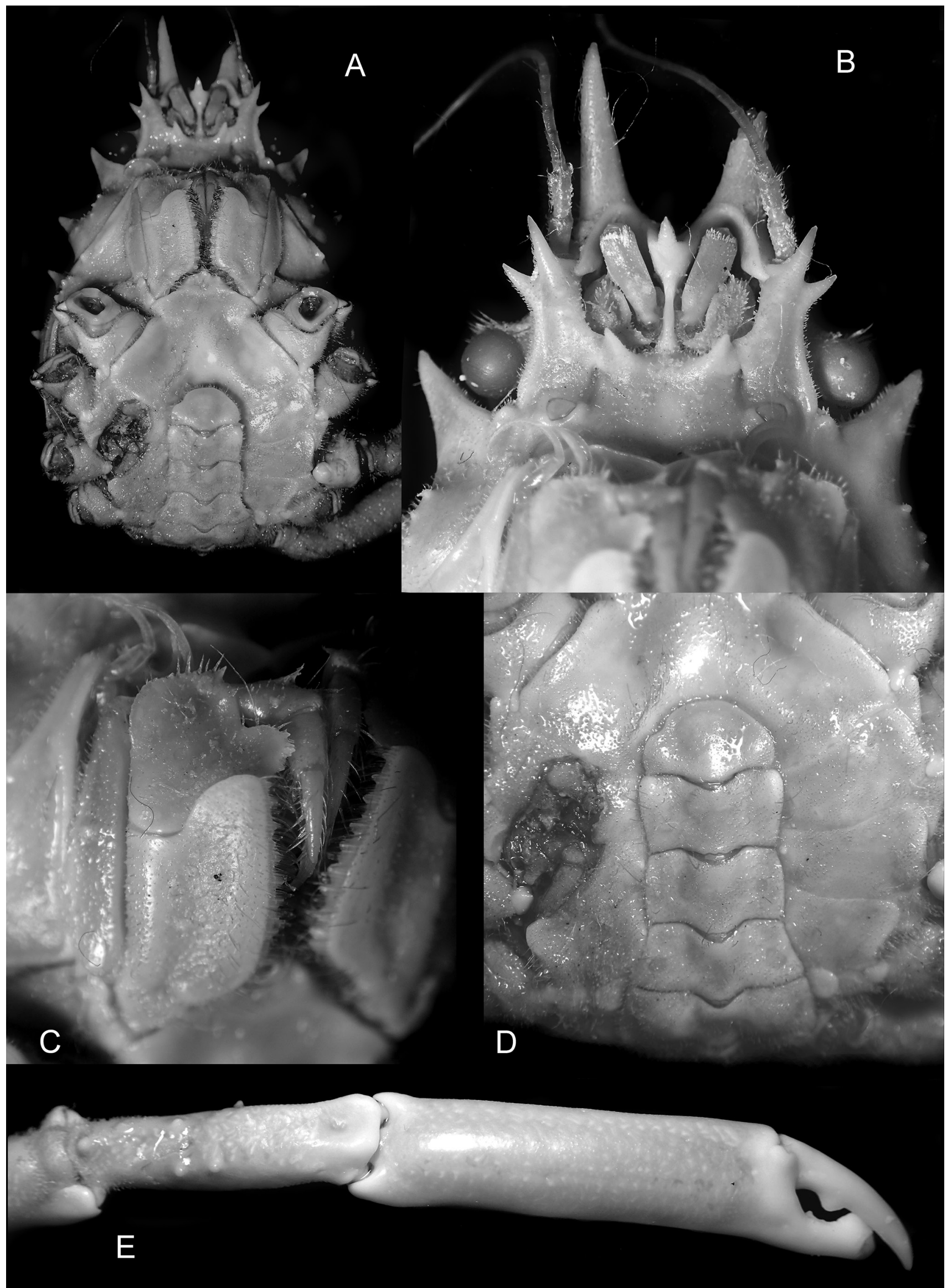

Figure 3. Schizophroida colemani sp. nov., male holotype, cl $33.5 \mathrm{~mm}$, Lord Howe Island, AM P19606. (A) ventral surface; (B) anterior cephalothorax, ventral view; $(C)$ right maxilliped 3; $(D)$ pleon and sternum; $(E)$ right cheliped. 


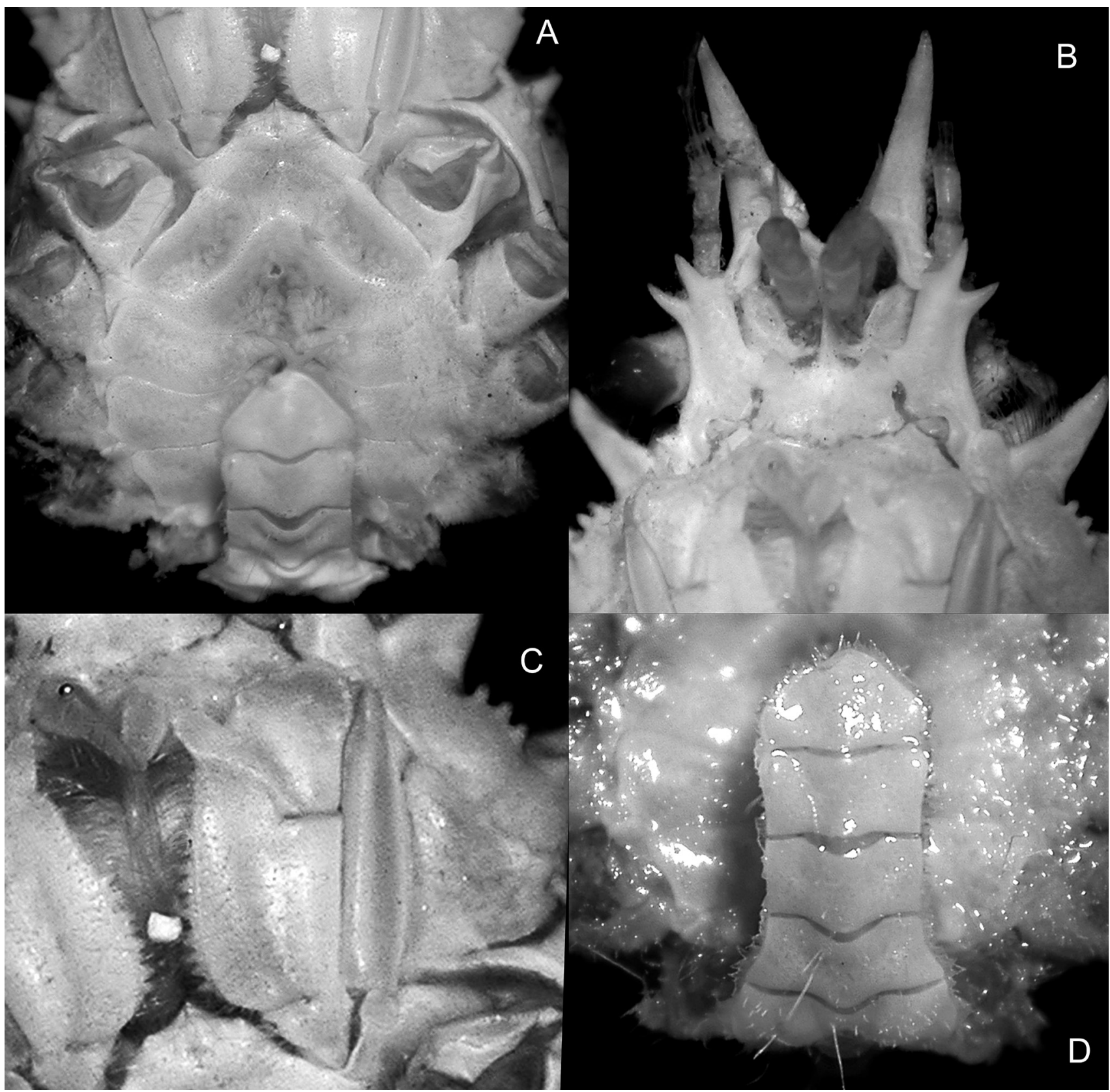

Figure 4. Schizophroida hilensis (Rathbun, 1906), male lectotype, cl $16.1 \mathrm{~mm}$, Hawaii, USNM 29794. (A) ventral surface; (B) anterior cephalothorax, ventral view; (C) left maxilliped 3; (D) pleon and sternum.

Dactylus slightly shorter than half palm length, occlusal margin with blunt tooth proximally. Carpus $2 / 3$ palm length in adult males, with 6-8 rounded granules (Figs 1A, B, 3E); in females, smooth, unarmed, as long as palm.

Pereopods $2-5$ strongly setose, unarmed; dactylus simple, with curved, corneous tip. Pereopod 2 longest, merus $0.41-0.62$ $\mathrm{pcl}$ (males), $0.42-0.46 \mathrm{pcl}$ (females). Pereopod 5 merus $0.27-0.36 \mathrm{pcl}$ (males), $0.28-0.32 \mathrm{pcl}$ (females) (Fig. 5A).

Male pleon with somite 4 trapezoidal, lateral margins weakly concave, margins converging distally; somites 5 and 6 subrectangular, margins weakly convex, widest at midlength and distal end, respectively; telson wider than long, distal margin evenly rounded (Fig. 3D).

G1 long, slender, with distal one-third distinctly curving laterally to about $50^{\circ}$ to longitudinal axis (Fig. 10A, B). G2 simple, distally bilobed, about one-fifth length of G2, exopod absent (Fig. 10C).
Etymology. The species is named after the late Neville Coleman, who collected most of the specimens of the type series.

Remarks. Griffin \& Tranter (1986) noted that specimens of Schizophroida from Australia, New Zealand and New Caledonia differed from Hawaiian material in the degree of carapace tuberculation and the relative length of the basal antennal spines, although they considered them to be conspecific. The present results indicate that the Australian and New Zealand population should be referred to a new species, herein named S. colemani sp. nov. The New Caledonian specimen appears to represent a different species again, discussed further below. As such, S. hilensis (Figs 1D, E, 2C, 4, 5B, 10D-F) is presently known with certainty only from the Hawaiian Islands.

In having a subdorsal posterolateral branchial tubercle on 
the carapace, $S$. colemani sp. nov. differs from $S$. simodaensis but resembles $S$. hilensis, S. moai, and S. gracilis sp. nov. Distinctions between $S$. colemani and $S$. gracilis are discussed under the account of the latter. Schizophroida colemani resembles $S$. hilensis in the strong curvature of the G1 (Fig. 10A, D), but differs in the position of the distomesial lobe on the G1 (closer to the tip in $S$. colemani as in $S$. moai), the lengths of the distal spines of the basal antennal segment (inner spine longer than outer in S. colemani versus equal in S. hilensis; Figs 3B, 4B), the narrower supraorbital eave (less than half basal rostral width versus exceeding half basal rostral width; Fig. 2A-C), in the presence of a transverse row of four prominent protogastic tubercles (at most two indistinct tubercles in S. hilensis; Fig. 2A-C), in subparallel versus divergent rostral spines (occasionally subparallel in S. hilensis; Figs 1, 2A-C), and a more evenly rounded male telson (Figs 3D, 4D). It should be noted that these differences are best observed in adults, in which the carapace tubercles and other structures are fully developed. Schizophroida colemani resembles S. moai in the distinctness of the carapace tubercles and the length of the basal antennal spines, but differs in having parallel instead of divergent rostral spines, less pronounced carapace spines in which the anterior branchial marginal spines are shorter, rather than subequal to hepatic spine, and the posterior spines are straight and slightly inclined dorsally, rather than upcurved. The male telson of $S$. moai is proportionally more elongate (Ng \& Boyko, 2017: fig. 13B versus Fig. 3D) and the G1 is also less strongly curved laterally than in $S$. colemani $(\mathrm{Ng}$ \& Boyko, 2017: fig. 17I, N versus Fig. 10A).

Schizophroida colemani matures between about 10 and $13.5 \mathrm{~mm}$ pcl, with sexual dimorphism in the more elongated, robust male chelipeds evident by about $15 \mathrm{~mm}$ pcl (Fig. $1 \mathrm{~A}-\mathrm{C})$. The smallest ovigerous female examined here measured $13.5 \mathrm{~mm}$ pcl, though Takeda \& Webber (2006) reported ovigerous specimens as small as $10.8 \mathrm{~mm}$. Slight dimorphism is also evident in the length of the ambulatory legs as indicated by the proportionally longer pereopod 5 merus in adult males $(0.33-0.36 \mathrm{pcl}$ in males; $0.29-0.31$ pcl females) (Fig. 1A-C). Juvenile males, however, have pereopod proportions similar to those of females.

Allometric variation in S. colemani is evident chiefly in the distinctness of the carapace tubercles, being most distinct in the largest specimens. The protogastric tubercles are usually absent in juveniles to about $10 \mathrm{~mm}$ pcl, and clearly evident by about $15 \mathrm{~mm}$ pcl. The protogastric tubercles can be indistinct in small specimens and are best observed by temporarily drying the surface of the gastric region. Similarly, the distinctness of the basal rostral tubercles is most pronounced in large specimens. The rostral spines are subparallel in all specimens except a few juveniles smaller than $10 \mathrm{~mm}$ pcl. In adult $S$. colemani, the outer basal antennal spine is shorter than the inner spine; however, the inner spine is initially the shorter in the smallest specimens ( $\mathrm{pcl} 3.1-4.3$ $\mathrm{mm}$; apparently first and second crab stage) becoming longer with increasing body size such that the spines are subequal by about $7 \mathrm{~mm}$ pcl and by about $9 \mathrm{~mm}$ pcl, the inner spine is longer than the outer spine.

As with many majoids, Schizophroida carries algal and other biofouling as camouflage. An ovigerous female of $S$. colemani (AM P53496) from off southern New South Wales was found with three janiroidean isopods and one specimen of the amphipod Dulichiella cf. australis (Haswell, 1879) (AM P53496) amongst the algal fouling on the carapace.
The northernmost records of $S$. colemani are from Lord Howe Island and the Kermadec Islands $\left(\sim 30-31^{\circ} \mathrm{S}\right)$ and southernmost records from Australia are off southern New South Wales $\left(35^{\circ} \mathrm{S}\right)$. In New Zealand, an ovigerous female was collected well south of its known natural range (Kermadecs) amongst biofouling on the floating wreck of a Taiwanese fishing vessel intercepted in 2007 in the Bay of Islands, northeastern New Zealand (Williams et al., 2008; as S. hilensis, NIWA (MITS) 21755). Schizophroida colemani is not known from mainland New Zealand; recruitment to the wreck probably occurred in the northern Tasman Sea in the vicinity of Lord Howe Island or the Kermadecs.

The specimen from New Caledonia reported by Griffin \& Tranter (1986) (juvenile female pcl $15.2 \mathrm{~mm}$, incomplete, lacking most pereopods, AM P29817; Fig. 3D) agrees with $S$. colemani in most respects but differs by its distinctly divergent and more elongate rostral spines $(0.25$ versus $0.13-0.22 \mathrm{pcl})$ and evidently matures at a larger size ( $S$. colemani matures between 10.8 and $13.5 \mathrm{~mm} \mathrm{pcl}$ ). The protogastric tubercles are small and best observed when the carapace surface is dried. Additionally, the New Caledonian specimen was collected much further north than the northernmost $S$. colemani (Kermadec Islands) and from 85-100 m depth, considerably deeper than other species of the genus (intertidal to shallow sublittoral depths not exceeding $30 \mathrm{~m}$ ). These bathymetric differences may be of significance; despite intensive sampling, Schizophroida has not been recorded from deeper waters around northern New Zealand including the Kermadec Ridge (Ahyong, 2008; Yaldwyn \& Webber, 2011). The New Caledonian specimen probably represents an undescribed species, but is retained here as Schizophroida sp. pending collection of mature and more complete specimens.

Distribution. Coastal southeastern Australia, the Tasman Sea (Lord Howe Island, Elizabeth Reef) and the Kermadec Islands, New Zealand; intertidal rocky and coral reefs to $30 \mathrm{~m}$.

\section{Schizophroida gracilis sp. nov.}

\author{
Figs 5C, D, 6-9, 10G-L \\ Schizophroida hilensis.-Paulay et al., 2003: 496 [Guam].- \\ Yang et al., 2008: 780 [Taiwan]. [Not Schizophroida \\ hilensis (Rathbun, 1906)].
}

Holotype: NTOU, male (cl $20.6 \mathrm{~mm}$, pcl $11.5 \mathrm{~mm}$, cw 10.5 $\mathrm{mm}$ ), Lanyu Island, Taitung County, $22^{\circ} \mathrm{N} 121^{\circ} \mathrm{W}$, coll. S.-H. Wu, August 2000. Paratypes: ZRC 2017.1026, 1 male (cl $21.3 \mathrm{~mm}$, pcl $15.5 \mathrm{~mm}, \mathrm{cw} 10.8 \mathrm{~mm}$ ), 2 females (cl 20.5 $\mathrm{mm}$, pcl $15.8 \mathrm{~mm}$, cw $11.0 \mathrm{~mm}$; cl $22.8 \mathrm{~mm}$, pcl $17.6 \mathrm{~mm}$, cw $12.0 \mathrm{~mm}$ ), Lanyu Island, 4-5 m, reefs, coll. S.-H. Wu, 7 October 1997-August 2000; AM P101292, 1 female (cl $22.7 \mathrm{~mm}$, pcl $17.1 \mathrm{~mm}$, cw $12.0 \mathrm{~mm}$ ), same. All Taiwan.

Other material examined. GUAM: ZRC 2000.625, 1 male (cl 15.1 $\mathrm{mm}$, pcl $11.8 \mathrm{~mm}$, cw $7.8 \mathrm{~mm} \mathrm{~mm}$ ), Pago Bay, reef front, under overhang, 5 m, coll. G. Paulay, 2 December 1995; ZRC 2000.626, 1 male (cl 21.1 mm, pcl $15.7 \mathrm{~mm}$, cw $10.8 \mathrm{~mm}), 1$ spent female (cl $19.5 \mathrm{~mm}$, pcl 15.4 $\mathrm{mm}$, cw $10.5 \mathrm{~mm}$ ), 1 ovigerous female (cl $17.7 \mathrm{~mm}$, pcl $13.6 \mathrm{~mm}, \mathrm{cw} 9.4$ $\mathrm{mm}$ ), beach, in channels, on walls, night dive, ca. $3 \mathrm{~m}$, coll. L. Kirkendale, 5 December 1998

Diagnosis. Rostral spines subparallel, margins slightly sinuous, longer than $0.25 \mathrm{pcl}$. Carapace protogastric region with transverse row of no more than 2 low tubercles in adults; posterolateral margin with subdorsal tubercle between posteromedian spines and posterior branchial marginal spine; 


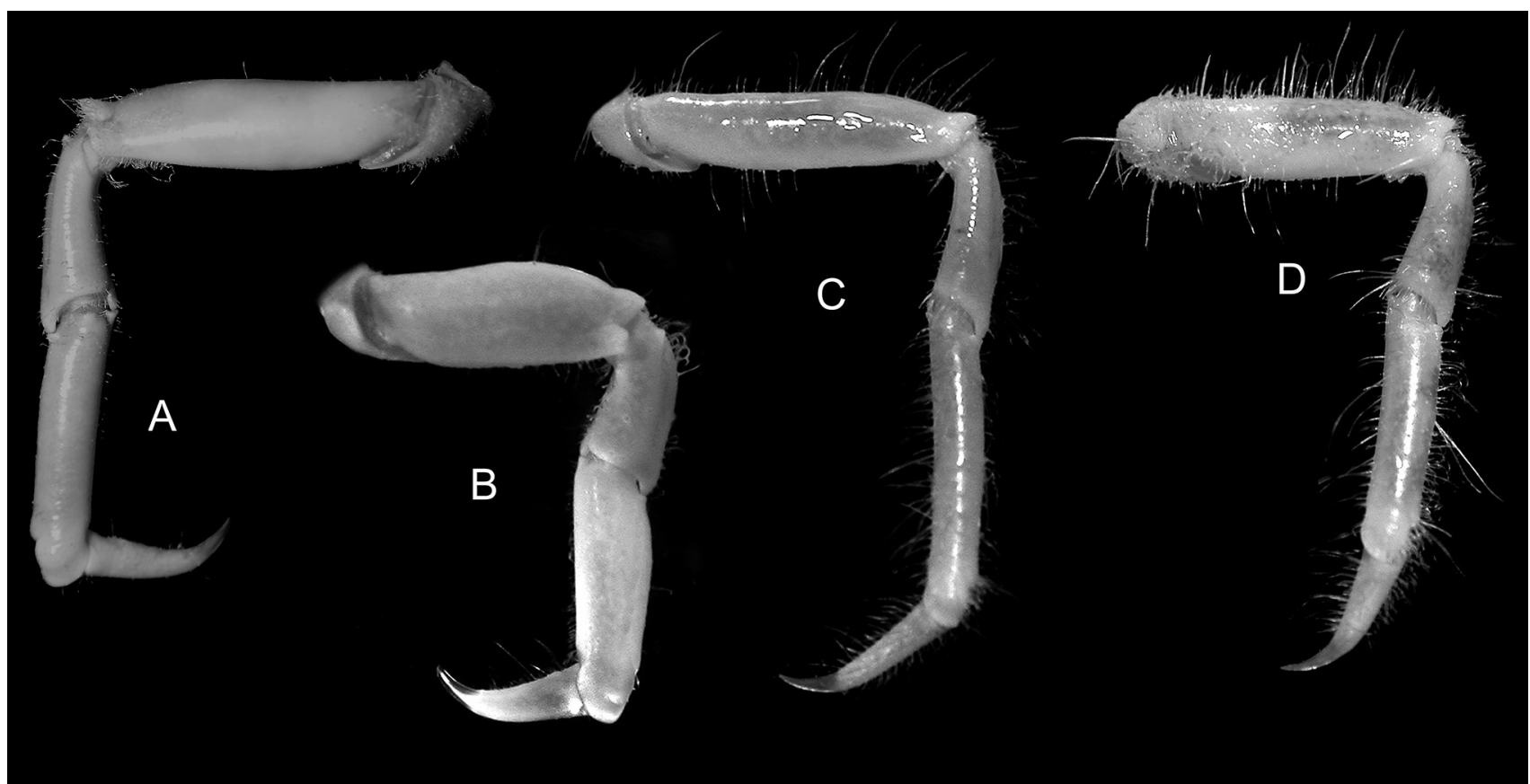

Figure 5. Schizophroida spp., pereopod 5 (A, left; B-D, right; A-C, setae removed). (A) S. colemani sp. nov., male holotype, cl 33.5 mm, Lord Howe Island, AM P19606; (B) S. hilensis (Rathbun, 1906), male, cl 12.4 mm, Hawaii, ZRC 2000.459; (C) S. gracilis sp. nov., holotype male, cl $20.6 \mathrm{~mm}$, Taiwan, NTOU; (D) S. gracilis sp. nov., male, cl 21.1 mm, Guam, ZRC 2000.626.

marginal branchial spines and posteromedian spines straight. Basal antennal article with inner distal spine longer than outer. Supraorbital eave transversely narrow, anterior width distinctly narrower than half basal width of rostral spine; intercalated spine small, triangular, directed almost laterally, separated from posterior spine of supraorbital eave by wide sinus with divergent margins. G1 with distal half distinctly curving laterally about $80^{\circ}$ to longitudinal axis.

Description. Carapace (Figs 6, 7) distinctly pyriform, longer than wide, regions weakly defined, surface densely covered with coarse straight and hooked setae. Rostral spines $0.27-0.38 \mathrm{pcl}$, margins slightly sinuous, subparallel. Supraorbital eave transversely narrow, anterior width distinctly narrower than half basal width of rostral spine; intercalated spine small, triangular, directed almost laterally, separated from posterior spine of supraorbital eave by wide sinus with divergent margins. Carapace postfrontal region with longitudinal row of 2 tubercles behind each rostral spine; gastric region with low tubercles: protogastric with low to prominent granule on each side; mesogastric with 1 very low, indistinct tubercle; cardiac region with very low, indistinct granule; intestinal region with low tubercle. Hepatic region inflated; prominent, broad, conical, laterally directed spine, larger than branchial spines; small subhepatic granules. Lateral branchial margin with 4 spines; posterior branchial margin with blunt subdorsal tubercle positioned midway between last branchial spine and paired posterior carapace spines (subdorsal tubercle indistinct in $17.1 \mathrm{~mm} \mathrm{pcl}$ female; AM P101292). Posterior carapace spines straight, directed posteriorly, inclined slightly dorsad.

Epistome (Figs 8B, 9B) with stout anteroventrally directed spine at base of each antennular sinus. Interantennular septum cristate; interantennular spine recurved anteriorly, clearly visible in dorsal view (Fig. 7). Basal antennal article distally bispinous, inner spine longer than outer spine (Fig. 8B).

Maxilliped 3 merus with rounded proximomesial lobe, margins usually with small denticles, distomesial margin with small spine; ischium distomesially auriculiform (Figs 8C, 9C).

Cheliped 1.19-1.64 pcl (male), 1.10-1.26 pcl (female); articles subcylindrical to subovate in cross-section. Propodal palm smooth, fingers with gape in adult males, pollex occlusal margin with blunt tooth near midlength. Dactylus slightly shorter than half palm length, occlusal margin with blunt tooth proximally. Carpus two-thirds to three-fourths palm length in adult males, with 8-11 rounded granules (Fig. 6A, C); in females, smooth, unarmed, as long as palm.

Pereopods 2-5 strongly setose, unarmed; dactylus simple, with curved, corneous tip. Pereopod 2 longest, merus $0.54-0.61 \mathrm{pcl}$ (males), $0.50-0.53 \mathrm{pcl}$ (females). Pereopod 5 merus $0.36-0.41 \mathrm{pcl}$ (males), $0.31-0.36 \mathrm{pcl}$ (females) (Figs $5 \mathrm{C}, \mathrm{D}, 6)$.

Male pleon with somite 4 trapezoidal, lateral margins weakly concave, margins converging distally; somites 5 and 6 subrectangular, margins weakly convex, widest at midlength and distal end, respectively; telson wider than long, distal margin evenly rounded (Figs 8D, 9D).

G1 long, slender, with distal half distinctly curving laterally about $80^{\circ}$ to longitudinal axis, becoming almost perpendicular (Fig. 10G, J). G2 simple, distally bilobed, about one-fifth length of G1, exopod absent (Fig. 10I, L).

Etymology. The species is named after its relatively long and slender pseudorostral spines and ambulatory legs.

Remarks. Schizophroida gracilis sp. nov. is distinctive in the genus in the possession of long, slightly sinuous, subparallel rostral spines $(0.27-0.38 \mathrm{pcl})$, a narrow supraorbital eave (anterior width distinctly narrower than half rostral spine width), a wide $\mathrm{V}$-shaped rather than narrow U-shaped sinus between the intercalated spine and the posterior spine of the supraorbital eave and a much more strongly bent G1 in which the distal portion becomes almost perpendicular to the proximal portion. Although most other species of 


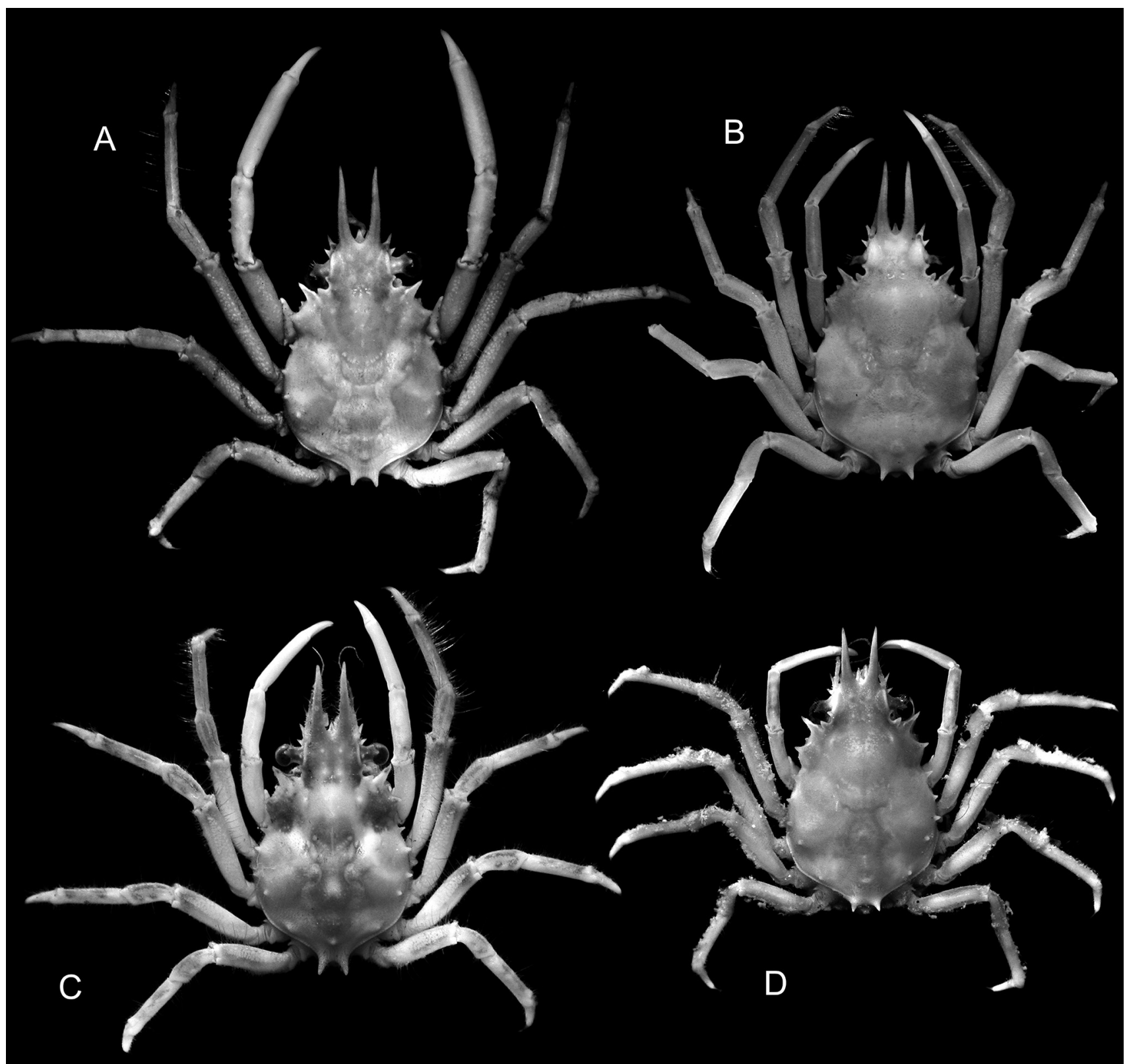

Figure 6. Schizophroida gracilis sp. nov., dorsal habitus (setae removed). (A) holotype male, 20.6 mm, Taiwan, NTOU; (B) paratype female, cl 22.8 mm, Taiwan, ZRC 2017.1026; (C) male, cl $21.1 \mathrm{~mm}$, Guam, ZRC 2000.626; (D) female, cl 19.5 mm, Guam, ZRC 2000.626.

Schizophroida have distinctly divergent rostral spines and a comparatively wide supraorbital eave, S. colemani also has subparallel rostral spines and a relatively narrow supraorbital eave. The rostral spines of $S$. colemani, however, are proportionately shorter than those of $S$. gracilis $(0.13-0.22$ versus $0.27-0.38 \mathrm{pcl}$ in adults), and the supraorbital eave is comparatively wider, but still narrower than half rostral spine width (Figs 3A, B, 4).

All examined specimens appear to be mature, with males having slightly more elongated walking legs and distinctly more robust chelipeds than females. Specimens from Taiwan and Guam are almost indistinguishable, but differ slightly in pereopod length as measured by the pereopod 5 merus. Taiwanese males have a proportionally longer pereopod 5 merus than those from Guam (0.38-0.41 pcl versus 0.36 $\mathrm{pcl})$, although corresponding measurements in females overlap (0.31-0.37 pcl versus $0.34 \mathrm{pcl}$ ) (Figs 5C, D, 6). Additionally, the cheliped of the largest male from Taiwan is more elongated (1.64 pcl versus $1.19 \mathrm{pcl})$ and more robust than a size-matched male from Guam (Fig. 2), suggesting that size at maturity might differ between the two populations. In the Taiwanese specimens, the lateral margins of male pleonites 4-6 are distincly more sinuous, with somite 4 more trapezoidal in shape compared to those from Guam (Figs 8D, 9D). The differences, however, are not substantial, and, like the length of the chelipeds, may be associated with maturity. It is possible that these differences indicate that the Taiwan and Guam populations belong to different species, but the available material does not provide sufficient evidence for this. The marked similarities in the structures of their carapaces, rostrums, and notably the G1s, suggest that it is best to treat the Taiwanese and Guam material as conspecific for the time being.

Distribution. Presently known only from Taiwan and Guam; rocky and coral reefs, 3-5 $\mathrm{m}$. 


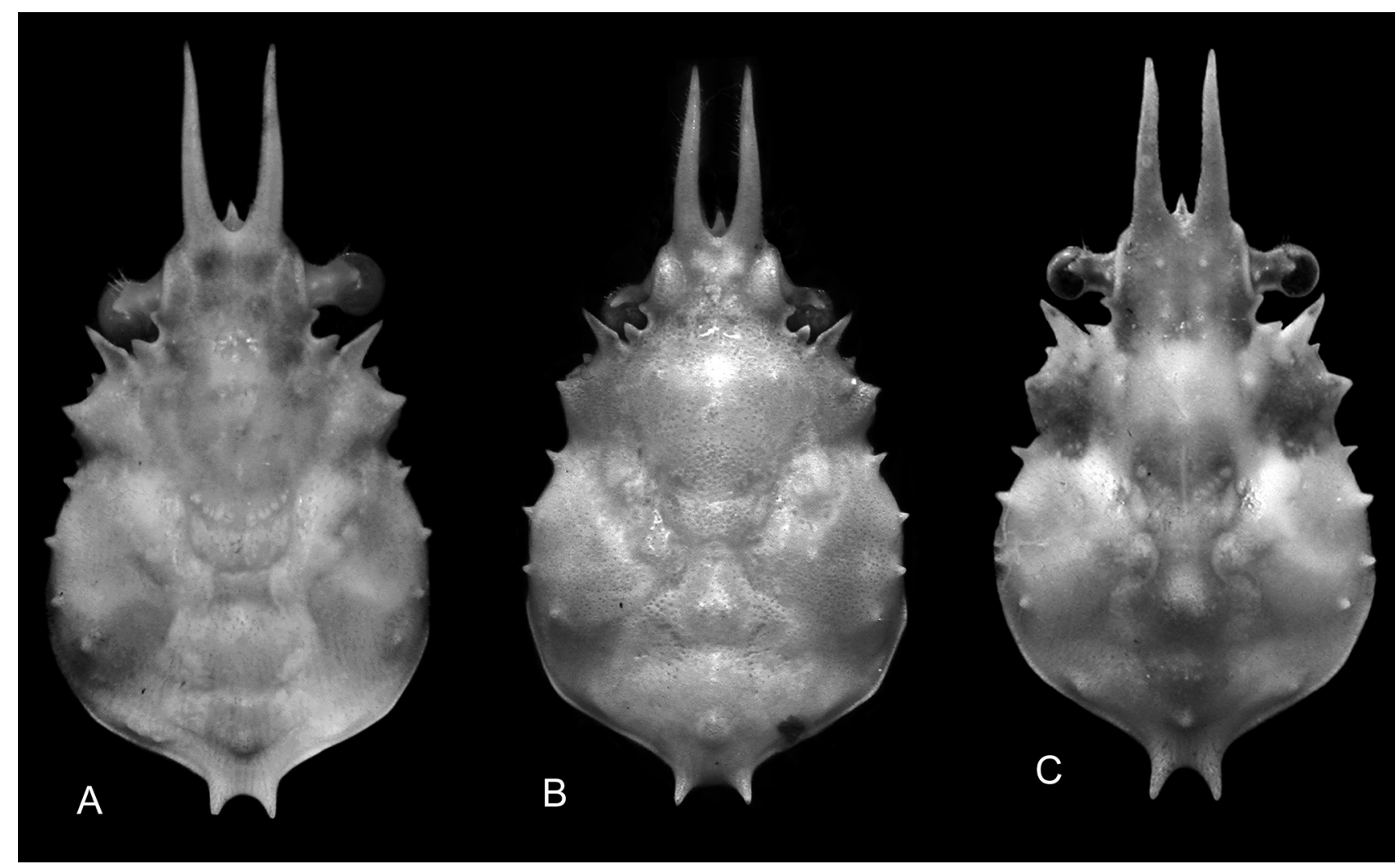

Figure 7. Schizophroida gracilis sp. nov., carapace (setae removed). (A) holotype male, cl $20.6 \mathrm{~mm}$, Taiwan, NTOU; (B) paratype female, cl 22.8 mm, Taiwan, ZRC 2017.1026; (C) male, cl $21.1 \mathrm{~mm}$, Guam, ZRC 2000.626.

\section{Key to species of Schizophroida}

$1 \quad$ Carapace posterolateral margin without subdorsal tubercle between posteromedian spines and posterior branchial marginal spine

[Japan] S. simodaensis Sakai, 1933

Carapace with posterolateral margin with subdorsal tubercle between posteromedian spines and posterior branchial marginal spine

2 Basal antennal article with inner distal spine as long as outer spine. Supraorbital eave anteriorly wider than half basal width of rostral spines [Hawaii] S. hilensis (Rathbun, 1906)

Basal antennal article with inner distal spine longer than outer spine. Supraorbital eave anteriorly narrower than half basal width of rostral spines

3 Sinus between intercalated spine and posterior spine of supraorbital eave wide, internal margins divergent [Taiwan, Guam] S. gracilis sp. nov.

Sinus between intercalated spine and posterior spine of supraorbital eave narrow, internal margins subparallel, U-shaped 4

4 Rostral spines divergent. Carapace marginal branchial spines and posteromedian spines curving upwards [Easter Island] S. moai Ng \& Boyko, 2017

Rostral spines subparallel. Carapace marginal branchial spines and posteromedian spines straight, although inclined upwards

.. [Australia, New Zealand] S. colemani sp. nov.

ACKNOWLEDGMENTS. We are grateful to Rafael Lemaitre and Karen Reed for their kind hospitality at the USNM in April 2016 and to Tin-Yam Chan (NTOU) for making the Taiwanese specimens available for study. Thanks are also due to Chan's former student, S.-H. Wu, who obtained the Taiwanese material many years ago and realized it was probably new to science, and kindly passed it to us for this study. The first author is most grateful to T. Sato (KPM) for permission to examine the specimens in the T. Sakai collection and his help with the data. We are grateful to Tomoyuki Komai (Natural History Museum and Institute, Chiba) and Tohru Naruse (University of the Ryukyus) for their constructive comments on the manuscript. We also gratefully acknowledge the Marine Invasives Taxonomic Service (MITS) funded by New Zealand Ministry of Primary Industries (MPI) and managed by Serena Cox (NIWA) for access to material from the Bay of Islands. 


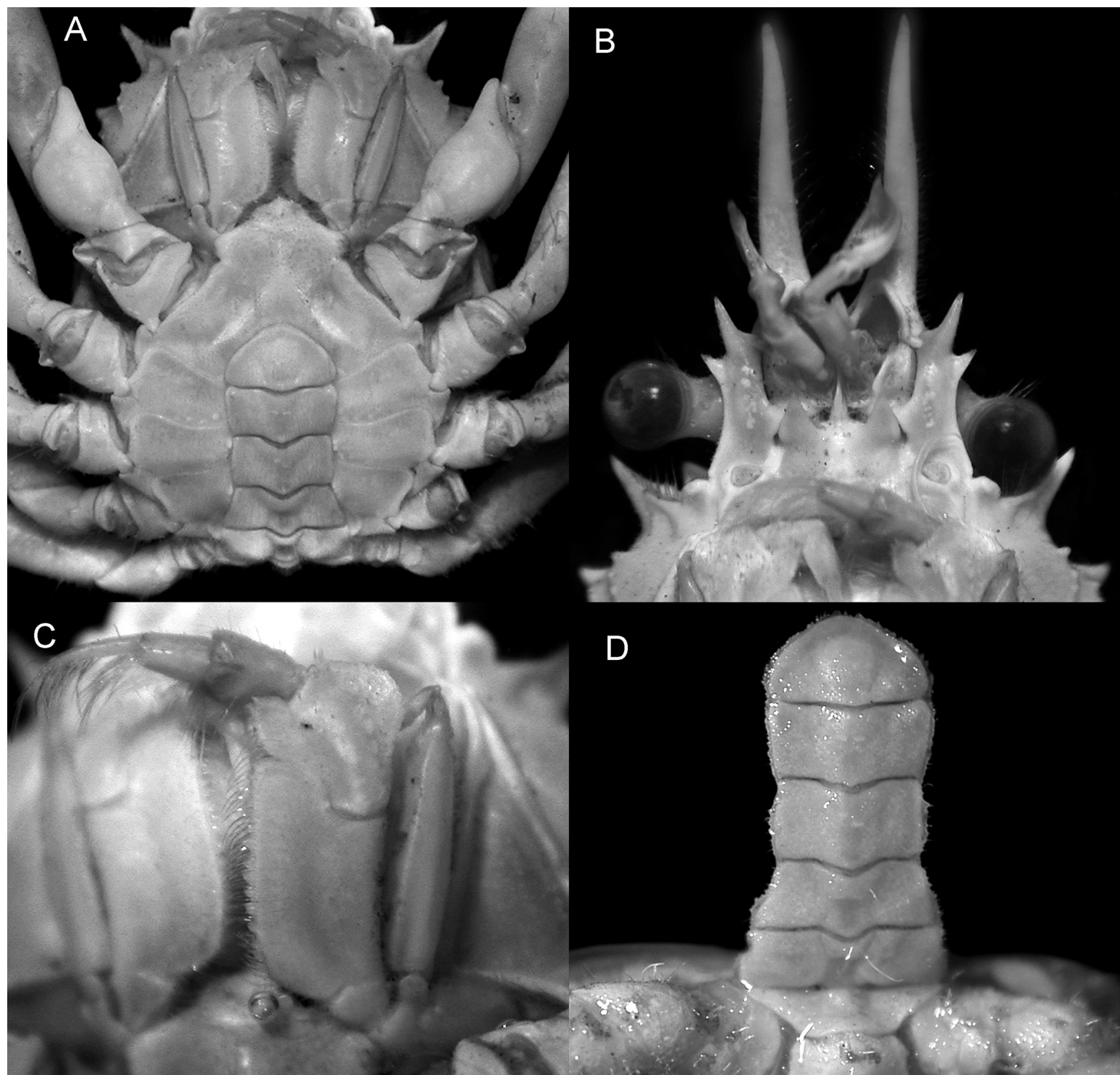

Figure 8. Schizophroida gracilis sp. nov., holotype male, cl $20.6 \mathrm{~mm}$, Taiwan, NTOU. (A) ventral surface; $(B)$ anterior cephalothorax, ventral view; $(C)$ right and left maxilliped 3; (D) pleon.

\section{References}

Ahyong, S. T. 2008. Deepwater crabs from seamounts and chemosynthetic habitats off eastern New Zealand (Crustacea: Decapoda: Brachyura). Zootaxa 1708: 1-72.

Ahyong, S. T. 2015. Decapod Crustacea of the Kermadec Biodiscovery Expedition 2011. Bulletin of the Auckland Museum 20: 405-442.

Ahyong, S. T., and S. L. Wilkens. 2011. Aliens in the Antipodes: non-indigenous Crustacea in New Zealand and Australia. In In the Wrong Place: Alien Marine Crustaceans-Distribution, Biology and Impacts. Invading Nature-Springer Series in Invasion Ecology, ed. B. S. Galil, P. F. Clark, and J. T. Carlton, pp. 451-485. Heidelberg: Springer Verlag. https://doi.org/10.1007/978-94-007-0591-3_16

Buitendijk, A. M. 1939. Biological Results of the Snellius Expedition. V. The Dromiacea, Oxystomata, and Oxyrhyncha of the Snellius Expedition. Temminckia 4: 223-276, pls. 7-11.

Chilton, C. 1911. The Crustacea of the Kermadec Islands. Transactions and Proceedings of the New Zealand Institute 43: 544-573.
Coleman, N. 2002. Lord Howe Island Marine Park: Sea Shore to Sea Floor. Springwood, Queensland: Neville Coleman's Underwater Geographic, 96 pp.

Duffy, C. A. J., and S. T. Ahyong. 2015. Annotated checklist of the marine fauna and flora of the Kermadec Islands Marine Reserve and northern Kermadec Ridge, New Zealand. Bulletin of the Auckland Museum 20: 19-124.

Griffin, D. J. G., and H. A. Tranter. 1986. The Decapoda Brachyura of the Siboga Expedition Part VIII, Majidae. Siboga-Expeditie 39: $1-335$.

Haswell, W. A. 1879. On Australian Amphipoda. Proceedings of the Linnean Society of New South Wales, 4(3): 245-279, pl. 7-12. https://doi.org/10.5962/bhl.part.22848

Ng, P. K. L., and C. B. Boyko. 2017. New species and records of crabs of the families, Dromiidae, Dynomenidae, Homolidae, Aethridae, Parthenopidae, Majidae and Epialtidae (Crustacea: Decapoda: Brachyura) from Easter Island, with a review of the majid genus Schizophroida Sakai, 1933. Pacific Science 71(2): 197-227. https://doi.org/10.2984/71.2.8 


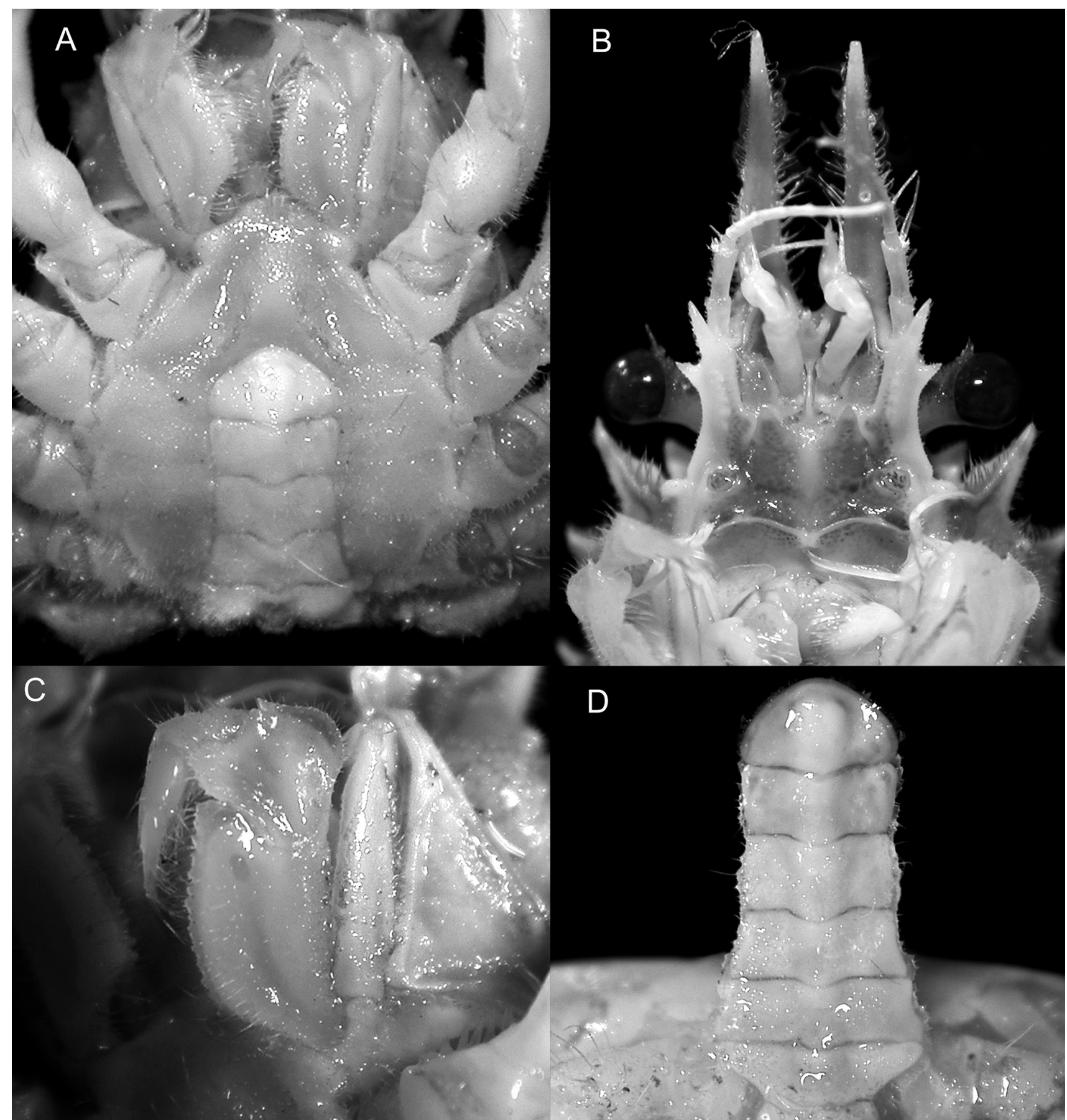

Figure 9. Schizophroida gracilis sp. nov., male, cl $21.1 \mathrm{~mm}$, Guam, ZRC 2000.626. (A) ventral surface; (B) anterior cephalothorax, ventral view; (C) left maxilliped 3; (D) pleon.

Ng, P. K. L., and B. Richer de Forges. 2012. Pleisticanthoides Yokoya, 1933, a valid genus of deep-sea inachid spider crabs (Crustacea: Decapoda: Brachyura: Majoidea), with descriptions of two new species from the Philippines, Papua New Guinea and Vanuatu. Zootaxa 3551: 65-81.

Paulay, G., R. Kropp, P. K. L. Ng, and L. G. Eldredge. 2003. The crustaceans and pycnogonids of the Mariana Islands. Micronesica 35-36: 456-513.

Poore, G. C. B. 2004. Marine Decapod Crustacea of Southern Australia: a Guide to Identification with Chapter on Stomatopoda by Shane Ahyong. Melbourne: CSIRO Publishing, 574 pp.

Rathbun, M. J. 1906. The Brachyura and Macrura of the Hawaiian islands. Bulletin of the United States Fish Commission 23(3): 827-930, pls. 1-24.
Sakai, T. 1933. A new genus and some new species of crabs from Simoda. Science Reports of the Tokyo Bunrika Daigaku, section B 1(12): 137-144, pl. 13.

Sakai, T. 1938. Studies on the crabs of Japan. III. Brachygnatha, Oxyrhyncha. Tokyo: Yokendo, pp. 193-364, pls. 20-26, tab. 1.

Sakai, T. 1976. Crabs of Japan and the Adjacent Seas. In three volumes: English Text, pp. xxix +773 pp.; Japanese text, pp. 1-461; plates volume, pp. 1-16, pls. 1-251. Tokyo: Kodansha Ltd.

Samouelle, G. 1819. The entomologist's useful compendium; or an introduction to the knowledge of British insects, comprising the best means of obtaining and preserving them, and a description of the apparatus generally used; together with the genera of Linné, and the modern method of arranging the classes 


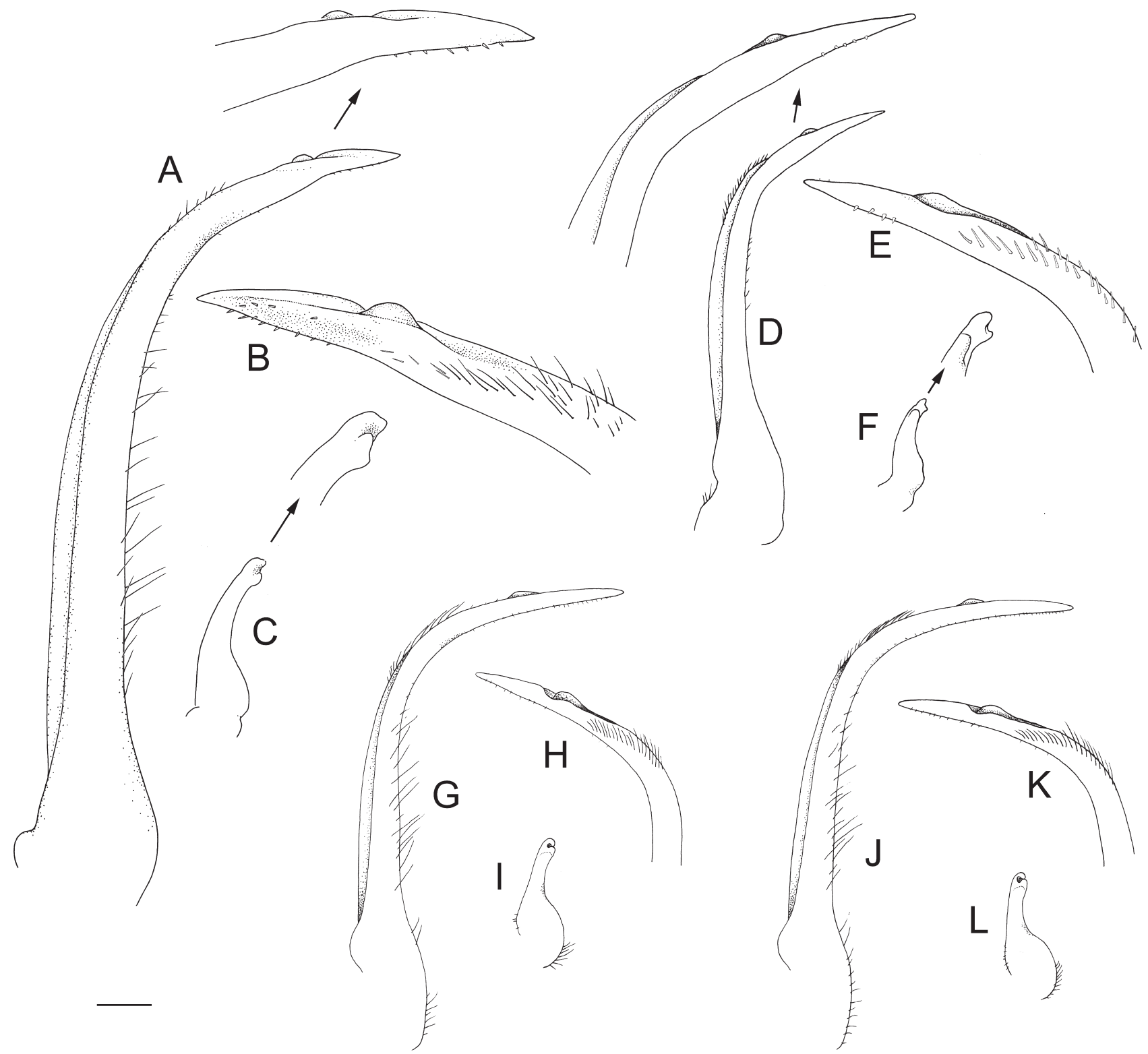

Figure 10. Schizophroida spp., G1 and G2. $(A-C)$ S. colemani sp. nov., male holotype, cl 33.5 mm, Lord Howe Island, AM P19606; $(D-F)$ S. hilensis (Rathbun, 1906), male lectotype, cl $16.1 \mathrm{~mm}$, Hawaii, USNM 29794; (G-I) S. gracilis sp. nov., holotype male, cl 20.6 mm, Taiwan, NTOU; (J-L) S. gracilis sp. nov., male, cl $21.1 \mathrm{~mm}$, Guam, ZRC 2000.626. A, D, G, J: left G1, abdominal view. B, E, H, $\mathrm{K}$ : left G1 distal end, sternal view. C, F, I, L: left G2, abdominal view. Scale: A, C, D, F, G-L = 0.5 mm, B, E = $0.25 \mathrm{~mm}$.

Crustacea, Myriapoda, Spiders, Mites and Insects, from their affinities and structure, according to the views of Dr. Leach. Also an explanation of the terms used in entomology; a calendar of the times of appearance and usual situations of near 3,000 species of British insects; with instructions for collecting and fitting up objects for the microscope. London: Thomas Boys, $496 \mathrm{pp}$.

Takeda, M. 1977. Crabs of the Ogasawara Islands, V. A collection made by dredging. Memoirs of the National Science Museum, Tokyo 10: 113-140, pls. 12-17, table 1.

Takeda, M., and W. R. Webber. 2006. Crabs from the Kermadec Islands in the South Pacific. In Proceedings of the 7th and 8th Symposia on Collection Building and Natural History Studies in Asia and the Pacific Rim, ed. Y. Tomida, T. Kubodera, S. Akiyama, and T. Kityama, pp. 191-237.

Webber, W. R., G. D. Fenwick, J. M. Bradford-Grieve, S. H. Eager, J. S. Buckeridge, G. C. B. Poore, E. W. Dawson, L. Watling, J. B. Jones, J. B. J. Wells, N. L. Bruce, S. T. Ahyong, K. Larsen, M. A. Chapman, J. Olesen, J.-S. Ho, J. D. Green, R. J. Shiel, C.
E. F. Rocha, A.-N. Lörz, G. J. Bird, and W. A. Charleston. 2010. Phylum Arthropoda. Subphylum Crustacea: shrimps, crabs, lobsters, barnacles, slaters, and kin. In New Zealand Inventory of Biodiversity, volume two. Kingdom Animalia: Chaetognatha, Ecdysozoa, Ichnofossils, ed. D. P. Gordon. Christchurch: Canterbury University Press, pp. 98-232.

White, A. 1848. Short descriptions of new or little-known decapod Crustacea. Proceedings of the Zoological Society of London 1847: 222-228. [Dated 1847, published 1848]

Williams, R., Gould, B., and S. Christian. 2008. Shipwrecks-an international biosecurity risk? Surveillance, 35(1): 4-6.

Yaldwyn, J. C., and W. R. Webber. 2011. Annotated checklist of New Zealand Decapoda (Arthropoda: Crustacea). Tuhinga 22: 171-272.

Yang, S., H. Chen, and W. Jiang. 2008. Infraorder BRACHYURA Latreille, 1803. In Checklist of Marine Biota China Seas, ed. J. Y. Liu, pp. 761-810. Beijing: Science Press, Academia Sinica. 